\title{
Protein phosphatase-2A is activated in pig brain following cardiac arrest and resuscitation
}

\author{
Tao T. Zhang • Jimcy Platholi • Paul M. Heerdt • \\ Hugh C. Hemmings Jr. • H. Y. L. Tung
}

Received: 10 April 2007 / Accepted: 25 September 2007 / Published online: 16 January 2008

(C) Springer Science + Business Media, LLC 2007

\begin{abstract}
Protein phosphatase-2A (PP-2A) interacts with several regulators of cell death pathways and is therefore a potential component of signaling pathways linking global cerebral ischemia to cell death. Using a novel procedure to quantify PP-2A activity, we find that cardiac arrest with resuscitation and reperfusion leads to activation of PP-2A by 1.6 -fold in pig brain extract and by 3.4 -fold after partial purification of PP-2A. This is the first demonstration of PP-2A activation in a clinically relevant model of transient global cerebral ischemia. These results suggest that inhibition of PP-2A activity may be neuroprotective in global cerebral ischemia.
\end{abstract}

Keywords Apoptosis · Necrotic cell death · Inhibitor-1 · Inhibitor-2 · Okadaic acid · Tautomycin

\section{Introduction}

Global cerebral ischemia triggers a series of cellular reactions that culminate in reversible or permanent cell injury (Siesjo 1988). Irreversible cell injury in the form of apoptotic and necrotic cell death contributes to brain damage associated with the extremely poor neurological outcome following cardiac arrest (Farber et al.1981;

T. T. Zhang • J. Platholi $\cdot$ P. M. Heerdt $\cdot$ H. C. Hemmings Jr. · H. Y. L. Tung

Institute for Neuronal Cell Signaling, Department of Anesthesiology,

Weill Medical College of Cornell University, New York, NY 10021, USA

J. Platholi • P. M. Heerdt • H. C. Hemmings Jr.

Department of Pharmacology, Weill Medical College of Cornell University, New York, NY 10021, USA

H. Y. L. Tung $(\bowtie)$

Laboratory of Neurobiochemistry, Institute for Neuronal Cell Signaling,

Department of Anesthesiology, Weill Medical College of Cornell University,

525 East 68th Street/LC 201/ Box 50, New York, NY 10021, USA

e-mail: hyltung@incsofweillcornell.org 
Siesjo 1988; Choi 1992; Martin et al.1998; Lipton 1999; Giffard 2000; Love 2003). Cell injury occurs both during the ischemic period and during the post-ischemic reperfusion period after successful resuscitation and return of spontaneous circulation as a result of reperfusion injury (Grinyo 1997). The cell signaling pathways that link global cerebral ischemia to the induction of cell death are not fully characterized. Depletion of ATP, loss of $\mathrm{Na}^{+}$pump function and ischemic depolarization lead to release of vesicular and cytoplasmic glutamate which activates ionotropic NMDA and AMPA glutamate receptors (excitotoxicity). The resulting increase in intracellular $\mathrm{Ca}^{2+}$ is a triggering event that activates multiple cell signaling pathways involved in ischemia-induced cell death (Olney 1969; Rothman and Olney 1986; Siesjo 1988; Choi 1992; Goldberg and Choi 1993; Lipton and Rosenberg 1994; Siesjo et al. 1995; Lipton 1999), but the mechanisms linking high $\mathrm{Ca}^{2+}$ and other intracellular signals (e.g. reactive oxygen species) to cell death are unknown.

Cell death due to global cerebral ischemia is highly regulated by protein phosphorylation and dephosphorylation (Small and Bucharan 1996; Wieloch et al. 1996). While the role of protein kinases in the control of cell death and/or poor neurological outcome in brain ischemia is well documented (Aronowski et al. 1992; Churn et al. 1992; Hu and Wieloch 1995; Shamloo and Wieloch 1999; Blanck et al. 2000; Shamloo et al. 2000; Bright et al. 2004), comparatively little is known about the protein phosphatases involved. Protein phosphatases previously implicated in the control of apoptotic cell death include protein phosphatase-1, protein phosphatase2A and protein phosphatase-2B (Klumpp and Krieglstein 2002; Garcia et al. 2003; Van Hoof and Goris 2003). Protein phosphatase-2A (PP-2A) is of particular interest because of its role in the induction of both apoptotic and necrotic (oncolytic) cell death (Kleinberger 2000; Chiang et al. 2002; Cicchillitti et al. 2003; Tamura et al. 2004; Janoo et al. 2005). Protein phosphatase-2A is a highly regulated heterooligomer that exists as multiple isoforms with varying distributions and substrate specificities (Cohen 1989; Jannssens and Goris 2001). We hypothesized that a form of PP-2A may be activated in global cerebral ischemia, and may link global cerebral ischemia to the control of apoptosis and necrotic cell death. We now present evidence that PP-2A is activated in pig brain following cardiac arrest with resuscitation and reperfusion.

\section{Materials and methods}

\section{Materials}

ATP, benzamidine, DEAE sepharose, poly-L-lysine agarose, phenylmethylsulfonyl fluoride (PMSF), protamine, phosphorylase b, PKA and bovine serum albumin were from Sigma (Saint Louis, MO). $\left[\gamma^{3}{ }^{32} \mathrm{P}\right]$ ATP was from GE Healthcare (Piscataway, NJ, USA).

\section{Protein preparation}

Bacterially expressed human inhibitor-1, human inhibitor-2 and human phosphorylase kinase $\gamma$ were purified by chromatography on a Ni-agarose column as Springer 
recommended by the manufacturer (Invitrogen, Carlsbad, CA, USA). ${ }^{32} \mathrm{P}$-labeled phosphorylase a was prepared by phosphorylation of phosphorylase $b$ by phosphorylase kinase as described (Cohen et al. 1988). Inhibitor-1 was phosphorylated by PKA as described (Hemmings et al. 1984). Protein concentration was determined by the method of Bradford (Bradford 1976) using bovine serum albumin as standard.

\section{Assay of protein phosphatase-2A}

PP-2A was assayed for its ability to dephosphorylate ${ }^{32} \mathrm{P}$-labeled phosphorylase a following activation by protamine. The assay consisted of $0.01 \mathrm{ml}$ of PP-2A in $50 \mathrm{mM}$ imidazole-Cl pH 7.2, $0.2 \mathrm{mM}$ EGTA, 0.1\% (v/v) 2-mercaptoethanol, $1 \mathrm{mg} / \mathrm{ml}$ bovine serum albumin (enzyme diluent buffer); $0.01 \mathrm{ml} 50 \mathrm{mM}$ imidazole- $\mathrm{Cl} \mathrm{pH} 7.2$, $0.2 \mathrm{mM}$ EGTA, $0.1 \%(v / v)$ 2-mercaptoethanol, $1 \mathrm{mg} / \mathrm{ml}$ bovine serum albumin, $100 \mathrm{nM}$ phospho- $\mathrm{T}^{35}$-inhibitor-1 or $1 \mu \mathrm{M}$ inhibitor- 2 and $30 \mu \mathrm{g} / \mathrm{ml}$ protamine sulfate (enzyme assay buffer); and $0.01 \mathrm{ml}$ of ${ }^{32} \mathrm{P}$-labeled phosphorylase a in enzyme diluent buffer plus $75 \mathrm{mM}$ caffeine. PP-2A was preincubated with protamine in enzyme assay buffer for $5 \mathrm{~min}$ at $30^{\circ} \mathrm{C}$ prior to initiation of protein phosphatase assay with ${ }^{32} \mathrm{P}$-labeled phosphorylase a. Reactions proceeded for $10 \mathrm{~min}$ at $30^{\circ} \mathrm{C}$ and were terminated with $0.2 \mathrm{ml}$ of $25 \%(v / v)$ trichloroacetic acid. The resulting suspension was centrifuged at $10,000 \times \mathrm{g}$ for $5 \mathrm{~min}$, and $0.2 \mathrm{ml}$ of the supernatant which contained the released $\left[{ }^{32} \mathrm{P}\right]$-phosphate was analyzed in a liquid scintillation spectrophotometer by Cerenkov counting. One unit of enzyme activity catalyzes the dephosphorylation of $1 \mathrm{nmol}$ of phosphate per minute at $30^{\circ} \mathrm{C}$.

\section{Ischemia and reperfusion}

Animal experiments were approved by the Institutional Animal Care and Use Committee of Weill Medical College of Cornell University. The pig model of transient global cerebral ischemia was performed as described in (Gedeborg et al. 2001; Liu et al. 2002) with some modifications. Female Yorkshire pigs ( 25 kg) were sedated with tiletamine/zolazepam $(4.4 \mathrm{mg} / \mathrm{kg} \mathrm{IM})$ and xylazine $(2.2 \mathrm{mg} / \mathrm{kg}$ IM). Anesthesia was induced with pentobarbital $(5 \mathrm{mg} / \mathrm{kg}$ bolus IV), the trachea intubated, and mechanical ventilation initiated with $21 \%$ oxygen. Anesthesia was maintained by intravenous infusion of pentobarbital $(8 \mathrm{mg} / \mathrm{kg}$ per h) with $0.9 \% \mathrm{NaCl}$ at $5 \mathrm{ml} / \mathrm{kg}$ per h. Temperature was maintained at $37 \pm 0.5^{\circ} \mathrm{C}$ by a warming blanket. A femoral venous catheter and a femoral arterial catheter were placed for rapid drug infusion and arterial pressure monitoring. Median sternotomy was performed to expose the heart. Ventricular fibrillation was induced by rapid pacing (rate of 800 , output of $16 \mathrm{~mA}$ ) and was confirmed by electrocardiography and loss of systolic blood pressure $(<20 \mathrm{mmHg})$. Ventilation was discontinued at the onset of fibrillation. After 10 min of cardiac arrest, animals were resuscitated by IV administration of lidocaine $(1.5 \mathrm{mg} / \mathrm{kg})$, epinephrine $(500 \mu \mathrm{g})$, and sodium bicarbonate $(6 \mathrm{mEq})$ with open chest cardiac massage at $60 / \mathrm{min}$ for $2 \mathrm{~min}$, followed by internal defibrillation (20J-50J) and ventilation with $100 \% \mathrm{O}_{2}$. After defibrillation, systolic blood pressure was maintained at $>60 \mathrm{mmHg}$ with intermittent bolus of epinephrine. Following $2 \mathrm{~h}$ of reperfusion and ventilation with $100 \% \mathrm{O}_{2}$, animals were sacrificed with saturated 
$\mathrm{KCl}(10 \mathrm{ml}) \mathrm{IV}$, and the brain was removed quickly $(<3 \mathrm{~min})$ through a ventral approach by removing the mandible and extraction through the palate. Control animals were treated identically with a sham operation, except that a fatal dose of $\mathrm{KCl}$ was injected without ventricular fibrillation and resuscitation.

Partial purification of PP-2A

Brains ( $\sim 80 \mathrm{~g})$ from a control animal and an animal that underwent cardiac arrest/ resuscitation on the same day were treated identically for each experiment. Each brain was cut into small pieces and homogenized in five volumes of $50 \mathrm{mM}$ imidazole- $\mathrm{Cl} \mathrm{pH}$ 7.3, 2 mM EDTA, $2 \mathrm{mM}$ EGTA, 0.1\% (v/v) 2-mercaptoethanol, $1 \mathrm{mM}$ benzamidine, $0.1 \mathrm{mM}$ PMSF and $5 \%(v / v)$ glycerol using $6 \times 30 \mathrm{~s}$ pulses at low speed in a blender. The homogenate was centrifuged at $10,000 \times \mathrm{g}$ for $30 \mathrm{~min}$ and the supernatant (the soluble extract) was collected, diluted twofold in $25 \mathrm{mM}$ imidazole- $\mathrm{Cl} \mathrm{pH}$ 7.3, $0.2 \mathrm{mM}$ EGTA, 0.1\% (v/v) 2-mercaptoethanol, $1 \mathrm{mM}$ benzamidine, $0.1 \mathrm{mM}$ PMSF and 10\% $(v / v)$ glycerol (buffer A), and loaded onto a DEAE sepharose column $(2.5 \times 20 \mathrm{~cm})$ equilibrated in buffer $\mathrm{A}$. The column was washed with $300 \mathrm{ml}$ of buffer A plus $50 \mathrm{mM} \mathrm{NaCl}$ and then eluted with buffer A plus $300 \mathrm{mM} \mathrm{NaCl}$. Active fractions of PP-2A were collected, diluted tenfold with buffer A, and loaded onto a poly-L-lysine column $(1.5 \times 10 \mathrm{~cm})$ equilibrated in buffer A. The column was washed with $150 \mathrm{ml}$ of buffer A and eluted successively with $150 \mathrm{ml}$ of buffer A plus 50,100, 250 or $500 \mathrm{mM} \mathrm{NaCl}$. The active fractions from each elution were collected, concentrated by vacuum dialysis and stored at $-20^{\circ} \mathrm{C}$ in buffer A plus $50 \%(v / v)$ for up to 3 months.

\section{Statistics}

Data were analyzed by the Student's $t$ test; $p<0.05$ was considered statistically significant (Motulsky 2003). Concentration-effect data were fitted to a sigmoidal curve to determine $\mathrm{IC}_{50}$ values using Graphpad Prism v. 4.02 (Graphpad, San Diego, CA, USA).

\section{Results}

Soluble pig brain extracts contain high levels of phosphorylase phosphatase activity due to PP-1 and PP-2A (Yang and Fung 1985; Tung and Reed 1989; Tung 1997). PP-2A activity can be determined in the presence of a specific inhibitor of PP-1 (phospho-Thr ${ }^{35}$-inhibitor-1 or inhibitor-2) and protamine sulfate which activates PP2A but inhibits PP-1 (Fig. 1) (Ingebritsen and Cohen 1983; Ingebritsen et al. 1983; Tung et al. 1985). To investigate the role of PP-2A in transient global cerebral ischemia, the pig model of brain ischemia following cardiac arrest and resuscitation was used (Gedeborg et al. 2001; Liu et al. 2002). Whole brain PP-2A was activated by 1.6-fold following cardiac arrest with resuscitation and reperfusion compared to control (Fig. 2). More accurate measurement of PP-2A in brain extracts was obtained by partial purification of PP-2A using DEAE Sepharose and poly-L-lysine agarose chromatography (Fig. 3; Tung et al. 1985; Tung et al. 1997). The major peak of PP- 
Fig. 1 Measurement of PP-2A activity in pig brain. Soluble brain extract was prepared as described in Materials and methods. Phosphorylase phosphatase activity was determined in the absence or presence of 100 nM phospho-Thr ${ }^{35}$ inhibitor-1 or $1 \mu \mathrm{M}$ inhibitor-2 plus $10 \mu \mathrm{g} / \mathrm{ml}$ protamine sulfate. Both specific PP-1 inhibitors produced similar inhibition. Phosphorylase phosphatase activity measured in the presence of $100 \mathrm{nM}$ phospho-Thr ${ }^{35}$ inhibitor- 1 or $1 \mu \mathrm{M}$ inhibitor-2 and protamine is defined as PP$2 \mathrm{~A}$ activity. Mean $\pm \operatorname{SEM}(n=3)$

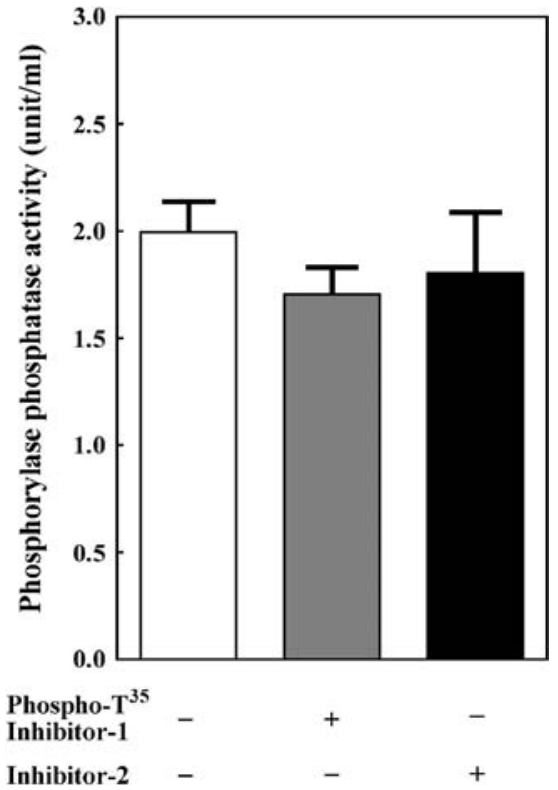

2A activity eluted at $500 \mathrm{mM} \mathrm{NaCl}$ after chromatography on poly-L-lysine agarose (Fig. 3b). Total PP-2A activity, quantified as the area under the peak, increased by 3.4-fold in ischemic following cardiac arrest and resuscitation with reperfusion compared to control (Fig. 3c).

Partially purified PP-2A from control and ischemic pig brain was not inhibited by phospho-inhibitor-1 or inhibitor-2, but was completely inhibited by okadaic acid $\left(\mathrm{IC}_{50}=2.1\right.$ and $5.4 \mathrm{nM}$, respectively) or tautomycin $(0.33$ and $0.86 \mathrm{nM}$, respectively),

Fig. 2 Activation of brain PP$2 \mathrm{~A}$ by cardiac arrest and resuscitation. The activity of PP-2A in soluble brain extract was determined in control pigs and in pigs subjected to $10 \mathrm{~min}$ of cardiac arrest followed by resuscitation and reperfusion for $2 \mathrm{~h}$. PP-2A activity was quantified as described in Fig. 1. Mean \pm SEM $(n=3) .{ }^{*} p<0.05$ vs control (Student's $t$ test)

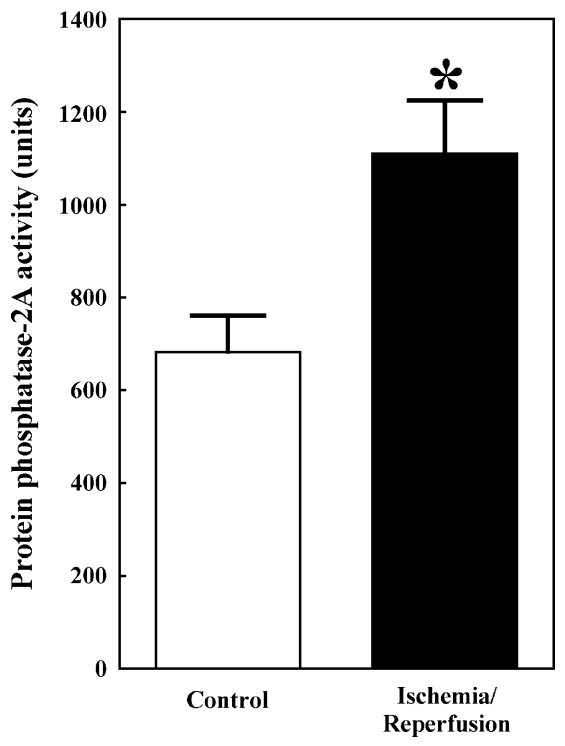

Springer 

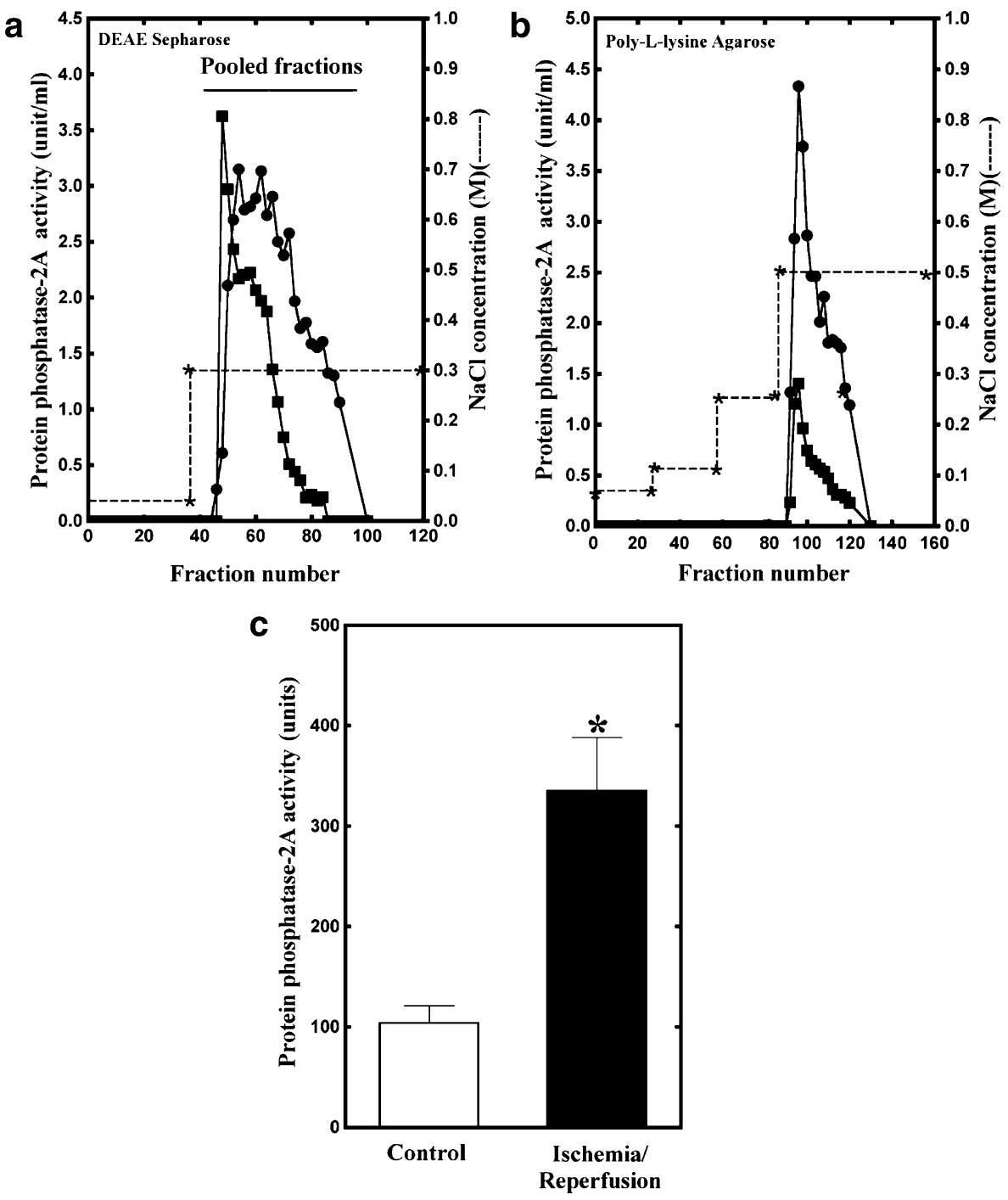

Fig. 3 Quantification of PP-2A activity from control and ischemic brain following partial purification. Soluble brain extracts from a control (non-ischemic) pig and a pig subjected to 10 min of cardiac arrest followed by resuscitation and reperfusion for $2 \mathrm{~h}$ were prepared as described in Materials and methods. a Extracts were loaded onto a DEAE sepharose column $(2.5 \times 20 \mathrm{~cm})$ which was washed and eluted at a flow rate of $60 \mathrm{ml} / \mathrm{h}$ with collection of $7 \mathrm{ml}$ fractions. PP-2A activity from control (square) and ischemic (circle) brain was determined as described in experimental procedures and Fig. 1. Data are shown for a single representative experiment $(n=3)$. b Active fractions from the DEAE column were pooled as indicated and loaded onto a poly-L-lysine agarose column which was washed and eluted at a flow rate of $30 \mathrm{ml} / \mathrm{h}$ with collection of $4.5 \mathrm{ml}$ fractions. PP-2A activity from control (square) and ischemic (circle) brain was determined. Data are shown for a single representative experiment $(n=3)$. c Total PP-2A activity from the poly-L-lysine agarose chromatography step was quantified as the area under the peak of activity. Mean \pm SEM $(n=3) .{ }^{*} p<0.05$ vs control (Student's $t$ test) 
confirming them as type 2A protein phosphatases (Fig. 4; Ingebritsen and Cohen 1983; Ingebritsen et al. 1983; Cohen et al. 1990; Hori et al.1991).

\section{Discussion}

Cardiac arrest followed by resuscitation and reperfusion increased the activity of a form of brain PP-2A. This represents the first demonstration of PP-2A activation by transient global cerebral ischemia in a clinically relevant animal model of cardiac arrest and resuscitation with reperfusion. PP-2A interacts with and dephosphorylates several proteins that are dephosphorylated upon initiation of apoptosis, including Bcl2, Bad and Rb (Chiang et al. 2002; Cicchillitti et al. 2003; Tamura et al. 2004). $\mathrm{PP}-2 \mathrm{~A}$ is also involved in the induction of necrotic (oncolytic) cell death in cell culture (Janoo et al. 2005). These findings suggest that a form of PP-2A may be an important component of the cell signaling pathway(s) that link ischemia to the control of cell death in transient global cerebral ischemia.

Protein phosphatase activation has been previously inferred in in vitro models of ischemia by the use of nonspecific inhibitors that target both PP-1 and PP-2A (Yung and Tolkovsky 2003). Using careful biochemical analysis, we were able to demonstrate directly the activation of PP-2A in transient global cerebral ischemia in vivo. This result is at variance with that published by Martin de la Vega et al. (2001, 2002) which used a rat model of transient global cerebral ischemia to demonstrate that PP-2A is inhibited in brain. The conflicting results may be due to
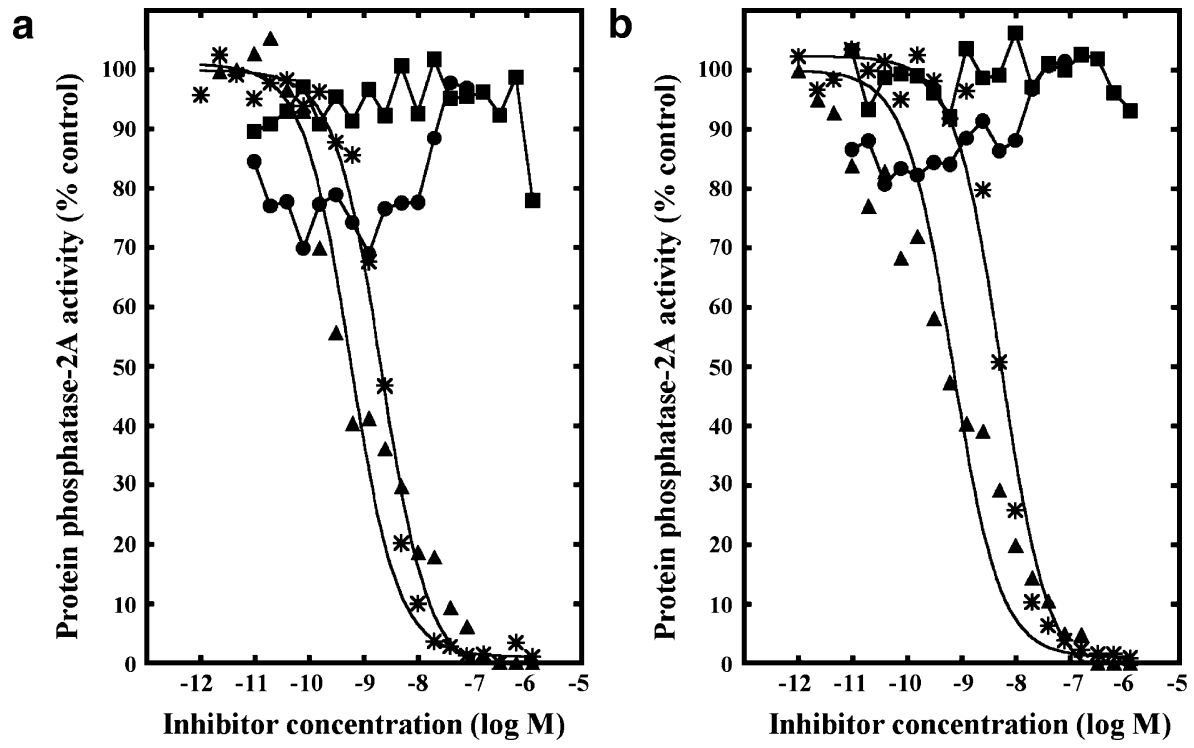

Fig. 4 Sensitivity of PP-2A from control and ischemic pig brain to various protein phosphatase inhibitors. PP-2A from control (a) and ischemic pig brain (b) obtained after partial purification by chromatography on DEAE Sepharose and poly-L-lysine agarose was assayed with various concentrations of phospho$\mathrm{Thr}^{35}$-inhibitor-1 (circle) inhibitor-2 (square), okadaic acid (star), and tautomycin (diamond). One hundred percent activity is equivalent to $0.005 \mathrm{U}$ 
the different methods used to achieve transient global cerebral ischemia and also to improper assay of PP-2A. There are several forms of PP-2A in brain. Activation of one form of PP-2A may imply depletion of another. The form of PP-2A that becomes activated in brain following cardiac arrest and resuscitation is currently being purified to near homogeneity. The mechanism of the pathophysiological activation of PP-2A in global cerebral ischemia and other diseases is unknown, as are the mechanisms that underlie its physiological activation. Viral proteins, including adenovirus E4orf4 protein and HIV-1 Vpr-derived C-terminal peptide, interact with and activate protein phosphatase- $2 \mathrm{~A}_{0}$ and/or protein phosphatase- $2 \mathrm{~A}_{1}$ (Shtrichman et al. 1999; Janoo et al. 2005). An intriguing hypothesis is that cellular homologues of these viral activators mediate PP-2A activation in vivo.

Cell death as a result of global cerebral ischemia is thought to be mediated in part by glutamate-induced elevation of intracellular $\mathrm{Ca}^{2+}$ which activates $\mathrm{Ca}^{2+}$-dependent protein kinases, protein phosphatases and proteases (Wieloch et al.1996). At least two $\mathrm{Ca}^{2+}$-dependent protein kinases, $\mathrm{Ca}^{2+1}$ calmodulin-dependent protein kinase II $(C a M K I I)$ and protein kinase $C \delta$ have been implicated as downstream components of $\mathrm{Ca}^{2+}$ cytotoxicity in global cerebral ischemia (Hu and Wieloch 1995; Bright et al. 2004) but their roles in activating cell death pathways and/or PP-2A are not known. This demonstration of a greater than threefold activation of PP-2A in global cerebral ischemia that is maintained through multiple purification steps suggests a covalent modification (e.g. phosphorylation) and/or stable molecular interaction (e.g. recruitment of an activating factor or subunit). Further characterization of the form of PP-2A activated in global cerebral ischemia should help clarify the mechanism(s) involved.

Acknowledgement This work was supported in part by the Department of Anesthesiology, Weill Medical College of Cornell University and the Phaekhim-Sekekos Foundation Fund for Biomedical Research.

\section{References}

Aronowski J, Grotto JC, Waxhan MN (1992) Ischemia-induced translocation of $\mathrm{Ca}^{2+} /$ calmodulindependent protein kinase II: potential role in neuronal damage. J Neurochem 58:1743-1753

Blanck TJJ, Halle M, Xu F, Heerdt P, Beckmann J, Kang R, Adamo A, Hemmings Jr HC (2000) Isoflurane pretreatment ameliorates postischemic neurological dysfunction and preserves hippocampal $\mathrm{Ca} 2+/$ calmodulin-dependent protein kinase II in a canine cardiac arrest model. Anesthesiology 93:1285-1283

Bradford AA (1976) A rapid and sensitive method for the quantitation of microgram quantities of protein utilizing the principle of protein-dye binding. Anal Biochem 76:248-254

Bright R, Raval AP, Dembner JM, Perez-Pinzon MA, Steinberg GK, Yenari MA, Mochly-Rosen D (2004) Protein kinase Cd mediates cerebral reperfusion injury in vivo. J Neurosci 24:6880-6888

Chiang CW, Harris G, Ellig C, Masters SC, Subramanian R, Shenolikar S, Wadszinski BE, Yang E (2002) Protein phosphatase-2A activates proapoptotic function of BAD in interleukin-3-dependent lymphoid cells by a mechansim requiring 14-3-3 dissociation. Blood 2001(97):1289-1297

Choi DW (1992) Excitotoxic cell death. J Neurobiol 23:1261-1276

Churn SB, Taft WC, Billingsley MS, Sankaran B, DeLorenzo RJ (1992) Global forebrain ischemia induces a posttranslational modification of multifunctional calcium- and calmodulin-dependent kinase II. J Neurochem 59:1221-1232

Cicchillitti L, Fasanaro P, Biglioli P, Capogrossi MC, Martelli F (2003) Oxidative stress induces protein phosphatase-2A-dependent dephosphorylation of the pocket proteins pRb, p107, and p130. J Biol Chem 278:19509-19517 
Cohen P (1989) The structure and regulation of protein phosphatases. Annu Rev Biochem 58:453-508

Cohen P, Alemany S, Hemmings BA, Resink TJ, Stralfors P, Tung HYL (1988) Protein phosphatase-1 and protein phosphatase-2A from rabbit skeletal muscle. Methods Enzymol 159:390-409

Cohen P, Holmes CF, Tsukitani Y (1990) Okadaic acid: a new probe for the study of cellular regulation. Trends Biochem Sci 15:98-102

Farber JL, Chien KR, Mittnacht Jr S (1981) The pathogenesis of irreversible cell injury in ischemia. Am J Pathol 102:271-281

Garcia A, Cayla X, Guergnon J, Dassauge F, Hospital V, Rebollo MP, Fleisher A, Rebollo A (2003) Serine/ threonine protein phosphatases PP1 and PP2A are key players in apoptosis. Biochimie 85:721-726

Gedeborg R, Silander HC, Rubertsson S, Wiklund L (2001) Cerebral ischaemia in experimental cardiopulmonary resuscitation -comparison of epinephrine and aortic occlusion. Resuscitation 50:319-329

Giffard RG (2000) Cell apoptosis in cerebral pathophysiology. Eur J Anaesthesiol 17:9-10

Goldberg MP, Choi DW (1993) Combined oxygen and glucose deprivation in cortical cell culture. J Neurosci 13:3510-3524

Grinyo JM (1997) Reperfusion injury. Transplant Proc 29:622-632

Hemmings Jr HC, Williams KR, Konigsberg WH, Greengard P (1984) DARPP-32, a dopamine- and adenosine 3':5'-monophosphate-regulated neuronal phosphoprotein. I. Amino acid sequence around the phosphorylated threonine. J Biol Chem 259:14486-14490

Hori M, Magae J, Han Y-G, Hartshorne DJ, Haraki H (1991) A novel protein phosphatase inhibitor, tautomycin. FEBS Lett 285:145-148

Hu B-R, Wieloch T (1995) Persistent translocation of $\mathrm{Ca}^{2+} /$ calmodulin dependent protein kinase II to synaptic junctions in the vulnerable hippocampal CA1 region following transient ischemia. J Neurochem 64:277-284

Ingebritsen TS, Cohen P (1983) The protein phosphatases involved in cellular regulation. 1. Classification and substrate specificities. Eur J Biochem 132:255-261

Ingebritsen TS, Stewart AA, Cohen P (1983) The protein phosphatases involved in cellular regulation. 6. Measurement of type-1 and type-2 protein phosphatases in extracts of mammalian tissues; an assessment of their physiological roles. Eur J Biochem 132:297-307

Jannssens V, Goris J (2001) protein phosphatase-2A: a highly regulated family of serine/threonine phosphatases implicated in cell growth and signaling. Biochem J 353:417-439

Janoo A, Morrow PW, Tung HYL (2005) Activation of protein phosphatase-2A1 by HIV-1 Vpr cell death causing peptide in intact CD4+ T cells and in vitro. J Cell Biochem 94:816-825

Kleinberger T (2000) Induction of apoptosis by adenovirus E4orf4 protein. Apoptosis 5:211-215

Klumpp S, Krieglstein J (2002) Serine/threonine protein phosphatases in apoptosis. Curr Opin Pharmacol 2:458-462

Lipton P (1999) Ischemic cell death in brain neurons. Physiol Rev 79:1431-1568

Lipton SA, Rosenberg PA (1994) Excitatory amino acids as a final common pathway for neurologic disorders. N Engl J Med 330:613-622

Liu X, Nozari A, Basu S, Ronquist G, Rubertsson S, Wiklund L (2002) Neurological outcome after experimental cardiopulmonary resuscitation: a result of delayed and potentially treatable neuronal injury. Acta Anaesthesiol Scand 46:537-546

Love S (2003) Apoptosis and brain ischemia. Prog Neuro-Psychopharmacol Biol Pyschiatry 27:267-282

Martin de la Vega C, Burda J, Salinas M (2001) Ischemia-induced inhibition of the initiation factor 2a phosphatase activity in the rat brain. NeuroReport 12:1021-1025

Martin de la Vega C, Burda J, Lobo MVT, Salinas M (2002) Cerebral postischemic reperfusion-induced demethylation of the protein phosphatase-2A catalytic subunit. J Neurosci Res 69:540-549

Martin LJ, Al-Abdulla NA, Brambrink AM, Kirsch JR, Sieber FE, Portera-Cailliau C (1998) Neurodegeneration in excitotoxicity, global cerebral ischemia, and target deprivation: a perspective on contributions of apoptosis and necrosis. Brain Res Bull 46:281-309

Motulsky HJ (2003) Prism 4 statistics guide - statistical analyses for laboratory and clinical researchers. Graphpad Software, Inc. San Diego, CA

Olney JW (1969) Brain lesion, obesity and other disturbances in mice treated with monosodium glutamate. Science 164:719-721

Rothman SM, Olney JW (1986) Glutamate and the pathophysiology of hypoxic-ischemic brain damage. Ann Neurol 19:105-111

Shamloo M, Wieloch T (1999) Changes in protein tyrosine phosphorylation in the rat brain after cerebral ischemia in a model of ischemic tolerance. J Cerebral Blood Flow Metabol 19:173-183 
Shamloo M, Kamme F, Wieloch T (2000) Subcellular distribution and autophosphorylation of calcium/ calmodulin-dependent protein kinase II-alpha in rat hippocampus in a model of ischemic tol erance. Neuroscience 96:665-674

Shtrichman R, Sharf R, Barr H, Dobner T, Kleinberger T (1999) Induction of apoptosis by adenovirus E4orf4 protein is specific in transformed cells and requires an interaction with protein phosphatase2A. Proc Natl Acad Sci 96:10080-10085

Siesjo BK (1988) Mechanisms of ischemic brain damage. Crit Care Med 16:954-963

Siesjo BK, Zhao Q, Pahlmark K, Siesjo P, Katsura K, Folbergrova J (1995) Glutamate, calcium and free radicals as mediators of ischemic brain damage. Ann Thorac Surg 59:1316-1320

Small DL, Buchanan AM (1996) Mechanisms of cerebral ischemia: intracellular cascades and therapeutic interventions. J Cardiothorac Vasc Anesth 10:139-146

Tamura Y, Smizu S, Osada H (2004) The phosphorylation status and anti-apoptotic activity of Bcl-2 are regulated by ERK and protein phosphatase-2A on the mitochondria. FEBS Lett 569:249-255

Tung HYL, Reed LJ (1989) Purification and characterization of protein phosphatase-1I activating kinase from bovine brain cytosolic and particulate fractions. J Biol Chem 264:2985-2990

Tung HYL, Alemany S, Cohen P (1985) The protein phosphatases involved in cellular regulation. 2. Purification, subunit structure and properties of protein phosphatase-2A0, 2A1 and $2 \mathrm{~A} 2$ from rabbit skeletal muscle. Eur J Biochem 148:253-263

Tung HYL, De Rocquigny H, Zhao L-J, Cayla X, Roques BP, Ozon R (1997) Direct activation of protein phosphatase-2A0 by HIV-1 encoded protein complex NCp7:Vpr. FEBS Lett 401:197-201

Van Hoof C, Goris J (2003) Phosphatases in apoptosis: to be or not to be, PP2A is in the heart of the question. Biochim Biophys Acta 1640:97-104

Wieloch T, Hu BR, Boris-Moller A, Cardell M, Kamme F, Kurihara J, Sakata K (1996) Intracellular signal transduction in the postischemic brain. Adv Neurol 71:371-387

Yang SD, Fung Y-L (1985) Identification and characterization of an ATP.Mg-dependent protein phosphatase from pig brain. J Biol Chem 260:13464-13470

Yung HW, Tolkovsky AM (2003) Erasure of kinase phosphorylation in astrocytes during oxygen-glucose deprivation is controlled by ATP levels and activation of protein phosphatases. J Neurochem $86: 1281-1288$ 